\title{
Protein/Peptide Substance
}

National Cancer Institute

\section{Source}

National Cancer Institute. Protein/Peptide Substance. NCI Thesaurus. Code C103227.

A substance that may be described as a discreet sequence of alpha-amino-acids connected through peptide bonds. 